\title{
Composição botânica e estrutural e valor nutricional de pastagens de azevém consorciadas
}

\author{
Fernando Reimann Skonieski ${ }^{1}$, Julio Viégas ${ }^{2}$, Rogério Fôlha Bermudes ${ }^{2}$, José Laerte \\ Nörnberg ${ }^{3}$, Magnos Fernando Ziech ${ }^{4}$, Olmar Antônio Denardin Costa ${ }^{5}$, Gilmar Roberto Meinerz ${ }^{1}$ \\ 1 Programa de Pós-graduação em Zootecnia, Universidade Federal de Santa Maria, Santa Maria, RS, Brasil. \\ 2 Departamento de Zootecnia, Universidade Federal de Santa Maria, Santa Maria, RS, Brasil. \\ ${ }^{3}$ Departamento de Tecnologia e Ciência dos Alimentos, Universidade Federal de Santa Maria, Santa Maria, RS, Brasil. \\ ${ }^{4}$ Universidade Tecnológica Federal do Paraná (UTFPR), Campus Dois Vizinhos, PR, Brasil. \\ ${ }^{5}$ Curso de Zootecnia, Universidade Federal de Santa Maria, Santa Maria, RS, Brasil.
}

RESUMO - Neste trabalho objetivou-se avaliar a influência de espécies em consórcio com azevém sobre a composição botânica e estrutural e o valor nutritivo dos pastos em um sistema de transição agroecológica. Foi avaliada a cultura do azevém (Lolium multiflorum Lam.) consorciada com aveia-preta (Avena strigosa Schreb.), trevo-branco (Trifolium repens L.) e amendoim-forrageiro (Arachis pintoi Krapov. \& Gregory). O delineamento experimental foi o inteiramente casualizado, com três tratamentos e três repetições. O primeiro pastejo foi realizado 21 dias após a emergência das plantas nas pastagens de azevém + aveia-preta e azevém + amendoim-forrageiro e 28 dias após a emergência na pastagem de azevém + trevo-branco. O segundo pastejo na pastagem de azevém + aveia-preta ocorreu 30 dias após o primeiro pastejo, enquanto nas demais pastagens ocorreu 37 dias depois. As taxas de acúmulo de matéria seca (MS) do início do período de exclusão até o pico de produção de MS foram de 77,7; 75,0 e 71,3 kg/ha/dia de MS para as pastagens consorciadas com trevo-branco, amendoim-forrageiro e aveiapreta, respectivamente. A razão folha/colmo até o segundo pastejo foi elevada em todas as pastagens. A redução dos teores de PB conforme os dias de exclusão no pasto de azevém + aveia-preta é menor que nos pastos de azevém consorciado com trevo-branco ou amendoim-forrageiro.

Palavras-chave: amendoim-forrageiro, aveia, digestibilidade, fibra em detergente neutro, leguminosa, trevo-branco

\section{Botanic and structural composition and nutritional value on intercropped ryegrass pastures}

\begin{abstract}
The objective of this work was to evaluate the influence of species intercropped with ryegrass on the botanical and structural composition and the nutritional values of pastures in an agroecological transition system. It was evaluated ryegrass (Lolium multiflorum Lam.) intercropped with black oats (Avena strigosa Schreb.), white clover (Trifolium repens L.) and forage peanut (Arachis pintoi Krapov. \& Gregory). It was used a complete random design with three treatments and three repetitions. The first grazing was done 21 days after emergence of the plants on the pastures with ryegrass and black oats and ryegrass and forage peanuts and 28 days after emergence on the pasture of ryegrass + white clover. The second grazing, on the pasture with ryegras + black oats, occurred 30 days after the first one, whereas on the other pastures, grazing occurred 37 days later. The rates of dry matter (DM) accumulation, from the beginning of period of exclusion until maximal production of dry matter were: $77.7 ; 75.0$ and $71.3 \mathrm{~kg} / \mathrm{ha} /$ day of DM for the pastures intercropped with white clover, forage peanut and black cover, respectively. Leaf/culm ratio until second grazing, was high on all pastures. Reduction on contents of crude protein according to exclusion days on ryegrass + black oat pasture is lower than on pastures of ryegrass intercropped with white clover or forage peanut.
\end{abstract}

Key Words: digestibility, forage peanut, legume, neutral detergent fiber, oat, white clover

\section{Introdução}

As pastagens são o principal componente das dietas de ruminantes e a fonte de alimentação mais econômica nos sistemas pecuários. Em sistemas de produção de leite, a melhor relação custo/beneficio da atividade baseia-se na utilização de volumosos de elevado valor nutricional. No entanto, aspectos como disponibilidade hídrica, condições de fertilidade do solo, manejo, temperatura e luminosidade podem definir a produtividade das pastagens.

O nitrogênio (N) é o mineral mais limitante ao desempenho produtivo de gramíneas e encontra-se em 
baixas concentrações no solo, em maior parte indisponível. Devido à elevada exigência desse mineral pelas plantas, de modo geral, a adubação nitrogenada é um recurso para aumentar a produção de MS e aumentar a produção animal por meio do aumento na taxa de lotação da pastagem. Hering \& Moojen (2002) observaram que a produção de milheto variou de $8.862 \mathrm{a} 17.403 \mathrm{~kg} / \mathrm{ha}$ de MS, respectivamente, para os níveis de adubação de 0 e 450 kg/ha de N; a dosagem superior a $450 \mathrm{~kg} /$ ha de N limitou o crescimento da pastagem.

A disponibilidade de nitrogênio no solo, assim como a sustentabilidade dos sistemas pastoris, pode ser melhoradas com a utilização de leguminosas em consórcio com gramíneas. Pesquisas comprovam que o uso de leguminosas em consórcio com gramíneas pode reduzir os gastos diretos com fertilizantes, aumentar a qualidade e a diversificação da dieta consumida pelos animais, melhorar a disponibilidade de forragem pelo aporte de nitrogênio ao sistema por meio de sua reciclagem e transferência para a gramínea consorciada e aumentar também o período de utilização das pastagens (Barcellos et al., 2008).

Neste estudo objetivou-se avaliar a composição botânica, morfológica e o valor nutritivo de pastagens de azevém consorciadas com aveia, trevo-branco ou amendoimforrageiro em um sistema de transição agroecológica com baixa utilização de insumos.

\section{Material e Métodos}

O experimento foi conduzido em área pertencente ao Laboratório de Bovinocultura de Leite do Departamento de Zootecnia da Universidade Federal de Santa Maria (UFSM) no período de 4 de junho a 31 de outubro de 2005. O local está situado na região fisiográfica da Depressão Central do Rio Grande do Sul, Brasil, a 95 m de altitude, 29 43' de latitude sul e $53^{\circ} 42^{\prime}$ de longitude oeste. O solo é classificado como Argissolo Vermelho Distrófico Arênico (Embrapa, 1999) e o clima da região é classificado como Cfa (subtropical úmido) conforme classificação de Köppen (Moreno, 1961), com precipitação média anual de 1.769 mm, temperatura média anual de $19,2^{\circ} \mathrm{C}$, com média mínima de $9,3^{\circ} \mathrm{C}$ em julho e média máxima de $24,7^{\circ} \mathrm{C}$ em janeiro, insolação de 2.212 horas anuais e umidade relativa do ar de $82 \%$.

As pastagens experimentais foram estabelecidas em um sistema de transição agroecológica, com baixa utilização de insumos e preparo mínimo do solo, após duas gradagens. O delineamento experimental foi o inteiramente casualizado, com três tratamentos e três repetições. A cultura do azevém (cv. Comum) foi avaliada em consórcio com aveia-preta (cv. Comum), trevo-branco (cv. Yi) e amendoim-forrageiro (cv. Amarillo). No consorcio com aveia-preta, a densidade de semeadura foi de $40 \mathrm{~kg} / \mathrm{ha}$ de azevém e $80 \mathrm{~kg} / \mathrm{h}$ a de aveia; no consorcio com azevém + trevo-branco, $40 \mathrm{~kg} / \mathrm{ha}$ de azevém e 4 kg/ha de trevo-branco; e no consórcio com amendoim-forrageiro, $40 \mathrm{~kg} / \mathrm{ha}$ de azevém e $12 \mathrm{~kg} / \mathrm{ha}$ de amendoim-forrageiro. O estabelecimento do amendoimforrageiro foi realizado em dezembro de 2004. A adubação de base constou de $40 \mathrm{~kg} /$ ha de fósforo e potássio, conforme recomendação da análise de solo (Comissão de Fertilidade do Solo RS/SC, 2004). A adubação de cobertura foi constituída de $20 \mathrm{~kg}$ de N/ha, em uma única aplicação, após o primeiro pastejo. O solo apresentou as seguintes características: $\mathrm{pH}-\mathrm{H}_{2} \mathrm{O}=5,0$; índice $\mathrm{SMP}=5,8 ; \mathrm{P}_{2} \mathrm{O}_{5}=$ $31,85 \mathrm{mg} / \mathrm{dm}^{3} ; \mathrm{K}_{2} \mathrm{O}=98,2 \mathrm{mg} / \mathrm{dm}^{3}$; matéria orgânica = 3,2\%; saturação de alumínio = 3\%; e saturação de bases $=58 \%$.

As áreas foram pastejadas com vacas da raça Holandesa em lactação, com peso médio de $530 \pm 30,5$ kg e produção média diária de $17 \pm 2,31 \mathrm{~kg} /$ dia, pelo método rotativo de pastejo, recebendo complementação alimentar com concentrado e silagem de milho. Os animais permaneceram nas áreas experimentais das 9 às 16 hs e das 18 às 7 h, com disponibilidade de sombra, água e sal mineral. O primeiro pastejo foi realizado aos dias após a emergência das plantas nas pastagens de azevém + aveia-preta e azevém + amendoim-forrageiro e aos 28 dias após a emergência na pastagem de azevém + trevo-branco. O segundo pastejo na pastagem de azevém + aveia-preta ocorreu 30 dias após o primeiro pastejo, enquanto, para as demais pastagens, ocorreu 37 dias depois.

Como critério para entrada dos animais, foi determinada a altura de $20 \mathrm{~cm}$ da pastagem em 20 pontos aleatórios, por meio de caminhamento diagonal nos piquetes, medindo-se a distância do solo até a altura do dobramento das folhas das gramíneas. Antecedendo a entrada, foi calculada a massa de forragem, estimada pela técnica de dupla amostragem, com cinco cortes e 20 estimativas visuais. Para determinação da carga animal a ser utilizada, procurou-se manter a oferta de forragem entre 8 e $10 \mathrm{~kg}$ de MS/100 kg de peso vivo, com base na massa de forragem estimada por dupla amostragem. A soma térmica acumulada durante o período de exclusão foi calculada pelo somatório da temperatura média diária, calculada pela soma da temperatura mínima com a temperatura máxima divididas por 2.

Dos dias 18 de junho a 31 de outubro, foram feitos cortes semanais a $5 \mathrm{~cm}$ do solo por área, com três repetições, utilizando-se um quadro de $0,30 \mathrm{~m}^{2}$. Cerca da décima parte dessas áreas $\left(100 \mathrm{~m}^{2}\right)$ foi isolada após o segundo pastejo, para avaliação do acúmulo de matéria seca. Cada corte foi pesado retirando-se cerca de $300 \mathrm{~g}$ de amostra. Realizou-se a separação do azevém e de seus componentes, colmo (bainha + haste), folha e inflorescência, bem como das 
espécies em consórcio, do material morto e das demais espécies não-quantificadas, que foram denominadas "outras espécies”. Em seguida, as amostras frescas foram pesadas, acondicionadas em sacos de papel, levadas à estufa com circulação de ar forçado a $55^{\circ} \mathrm{C}$ por aproximadamente 72 horas e, depois, foram pesadas para estimativa da produção por hectare de MS de cada componente da pastagem.

Das amostras pré-secas contendo apenas azevém, foram feitas estimativas de MS em estufa a $105^{\circ} \mathrm{C}$ durante 16 horas; proteína bruta (PB), pelo método micro-Kjeldahl, obtida pelo nitrogênio total multiplicado por 6,25; fibra em detergente neutro (FDN), conforme metodologia descrita por Goering \& Van Soest (1970), posteriormente corrigida para cinzas; e digestibilidade in vitro da matéria orgânica (DIVMO), de acordo com Tilley \& Terry (1963).

Os resultados foram submetidos à análise de variância. As médias dos tratamentos dentro de cada período foram comparadas utilizando-se o teste Tukey a 5\% de probabilidade de erro, enquanto a avaliação dos tratamentos entre os períodos foi realizada por análise de regressão, a $5 \%$ de probabilidade de erro (SAS, 2001).

\section{Resultados e Discussão}

As taxas de acúmulo de MS, considerando o período de exclusão até a produção de MS atingir o pico, foram de 77,7; 75,0 e 71,3 kg/ha de MS/dia, para as pastagens consorciadas com trevo-branco, amendoim-forrageiro e aveia-preta, respectivamente (Figura 1). A razão entre folhas e colmos até o segundo pastejo foi elevada em todas as pastagens. No momento do segundo pastejo, a razão folha/colmo foi de 6,76; 3,82 e 3,21 para o azevém consorciado com aveia, trevo-branco e amendoim-forrageiro, respectivamente (Figura 1). Durante o período experimental a razão folha/ colmo da cultura do azevém na pastagem de azevém + aveia-preta foi maior $(\mathrm{P}<0,05)$ que nas demais. De acordo com Rocha et al. (2007), a quantificação da proporção dos componentes da planta, especialmente a razão folha/colmo, é importante na comparação entre cultivares e espécies forrageiras, pois podem afetar o ganho de peso dos animais em pastejo.

A maior persistência de hastes em relação a folhas determinou o comportamento linear do componente colmo (Figura 2). Assim, conforme se passaram os dias de exclusão, houve inversão no acúmulo de folhas e colmos na cultura do azevém próximo aos 56, 35 e 35 dias, quando as produções de MS foram de 2.250, 1.750 e 1.500 kg/ha de MS de azevém nas pastagens consorciadas com aveia-preta, trevo-branco e amendoim-forrageiro. A menor produção de colmos de azevém foi observada na pastagem de azevém + aveia-preta.
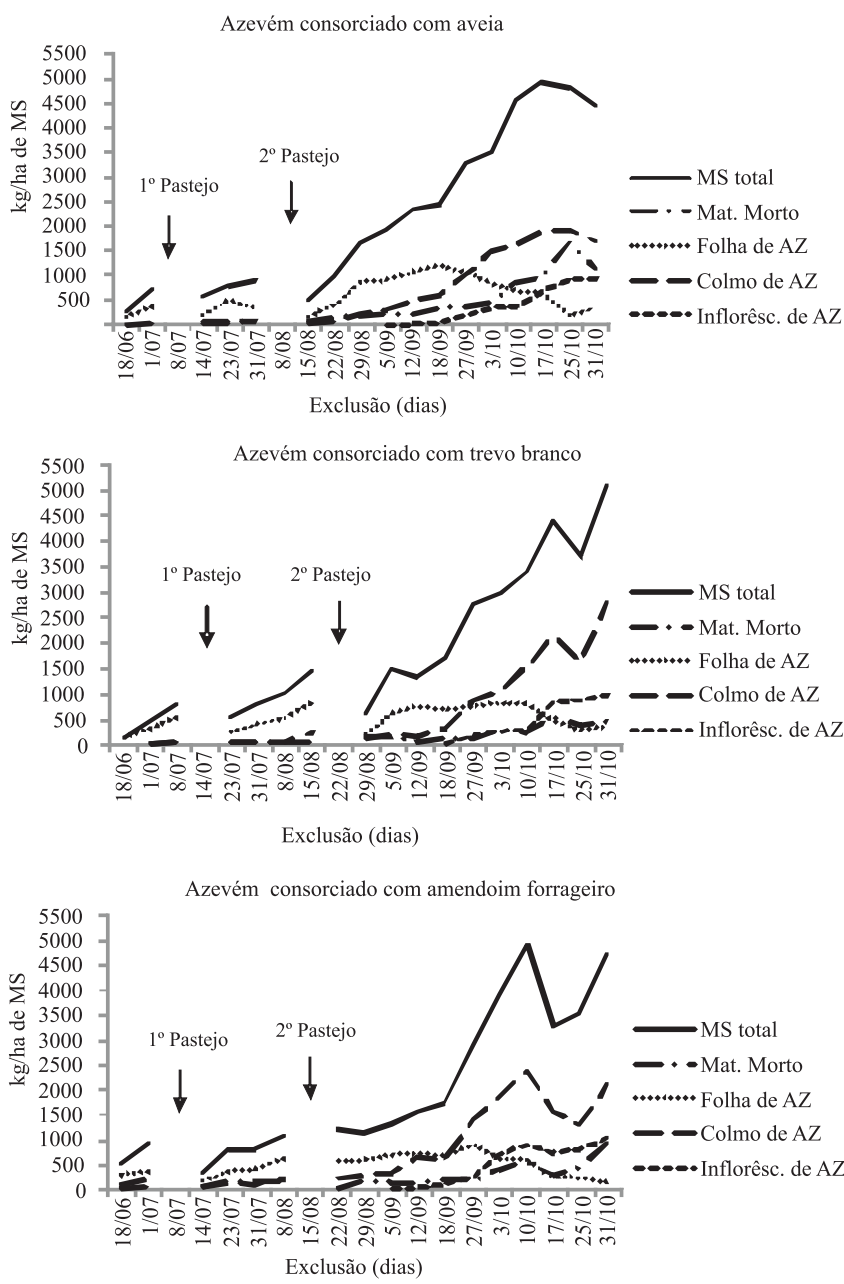

Figura 1 - Acúmulo de matéria seca total, material morto e composição estrutural do azevém consorciado durante dois ciclos de pastejo e após exclusão.

As variáveis folha e inflorescência ajustaram-se ao modelo de regressão quadrático (Figura 2). A maior produção de folhas de azevém foi observada na pastagem de azevém + aveia-preta. Grise et al. (2001) estudaram pastagens de aveia consorciadas com ervilhaca forrageira em várias alturas e observaram que a presença de folhas na MS aumenta a digestibilidade e o consumo animal.

O aparecimento de inflorescências de azevém na pastagem de azevém + aveia-preta ocorreu mais tardiamente, havendo menor produção e acúmulo dessa variável conforme o período de exclusão (Figura 2). O provável atraso no florescimento do azevém, bem como a menor produção de espigas, pode também ser atribuído à menor intensidade de luz incidente sobre a cultura do azevém, possivelmente em função do crescimento precoce da aveia. Autores propõem que a baixa intensidade luminosa prolonga o estádio vegetativo das plantas, resultando em atraso na floração de diversas espécies. O atraso na emissão das estruturas 

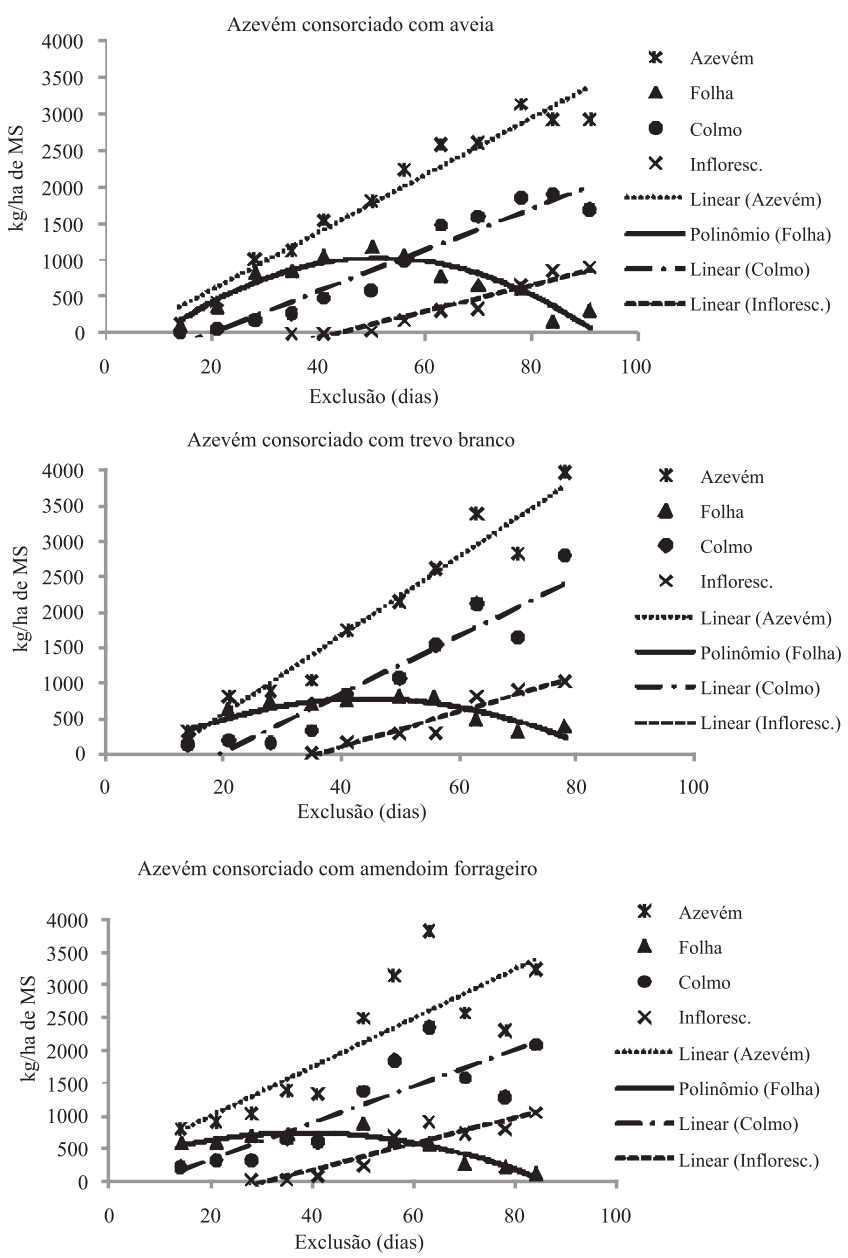

Figura 2 - Acúmulo dos componentes estruturais do azevém consorciado durante o período de exclusão.

florais, devido à baixa luminosidade ambiente, também foi constatado em Lolium perenne e Festuca pratensis por Ryle (1967) e em espécies tropicais por Castro \& Carvalho (2000). Em todas as pastagens, o início ou a maior emissão de inflorescências coincidiu com a inversão da proporção entre colmos e folhas (Figura 2). A consorciação de azevém e aveia-preta resultou em maior razão folha/ colmo e atrasou a entrada em estádio reprodutivo do azevém. Dessa forma, além do efeito característico da aveia em pastagens consorciadas de azevém antecipando a entrada dos animais na pastagem, devido à precocidade de produção de MS, permite também alongar o período de utilização da pastagem. O maior acúmulo de MS total ocorreu na pastagem de azevém e trevo-branco, devido à sua maior produção de azevém (Figura 2). O menor acúmulo de azevém foi observado na pastagem de azevém + aveiapreta e esse efeito também pode estar relacionado ao sombreamento causado pela aveia.

As outras espécies, as quais apresentaram crescimento espontâneo (Paspalum conjugatum, Urochloa plantaginea, Digitaria sanguinalis, Sida santaremnesis e Polygonum persicaria) mantiveram-se em baixas proporções e estáveis ao longo do período de avaliação, portanto não foram afetadas pela consorciação nem pelo período. Entre as espécies em consórcio, a maior produção foi observada para a aveia em relação às demais. A equação de regressão não foi significativa para a cultura do amendoim-forrageiro, logo não houve interação entre tratamento $\times$ período. $\mathrm{O}$ amendoim-forrageiro, por ser uma leguminosa estival, apresentou baixa produção de MS no período avaliado e não teve efeito na composição botânica, estrutural e nutricional da pastagem. O acúmulo de material morto foi maior na pastagem de azevém + aveia-preta, em virtude principalmente da maior contribuição de aveia em relação às outras espécies em consorciação com o azevém no período inicial de avaliação.

Na ausência de pastejo, e ainda em condições nãolimitantes ao crescimento, a velocidade como ocorre acúmulo de biomassa depende do tempo térmico decorrido, uma vez que a temperatura é o fator que regula a atividade meristemática. A variável folha ajustou-se ao modelo de regressão quadrático em todos os consórcios, alcançando o pico de produção com soma térmica de 787,817 e $815^{\circ} \mathrm{C}$ para as pastagens de azevém + amendoim-forrageiro, azevém + trevo-branco e azevém + aveia-preta, respectivamente. Apesar disso, a inversão dos componentes folha e colmo ocorreu quando o soma térmica alcançou 568, 699 e $942^{\circ} \mathrm{C}$ para as pastagens consorciadas com amendoimforrageiro, trevo-branco e aveia-preta. A inflorescência ajustou-se ao modelo de regressão linear para pastagem de azevém + amendoim-forrageiro e ao modelo quadrático para as pastagens de azevém + trevo-branco e azevém + aveia-preta. A deposição de inflorescência começou a ocorrer próximo ou logo após os $500^{\circ} \mathrm{C}$ nas pastagens consorciadas com amendoim-forrageiro e trevo-branco, enquanto o azevém na pastagem de azevém + aveia-preta necessitou de aproximadamente $800^{\circ} \mathrm{C}$ para começar a emitir inflorescências. O material morto apresentou comportamento linear em todos os consórcios.

O maior teor de PB foi observado no azevém consorciado com trevo-branco no início do período de exclusão, devido à maior participação da leguminosa ocorrida nesse período, que chegou a representar $24,75 \%$ da biomassa verde aos 35 dias de exclusão, possivelmente transferindo nitrogênio para a gramínea acompanhante, e também devido à maior razão folha/colmo do pasto nesse período (Figura 3). No entanto, entre os consórcios com trevo-branco e com aveia-preta, a razão folha/colmo do azevém associado com aveia foi maior em todos os períodos no início de avaliação e evidencia a eficiência do trevo- 

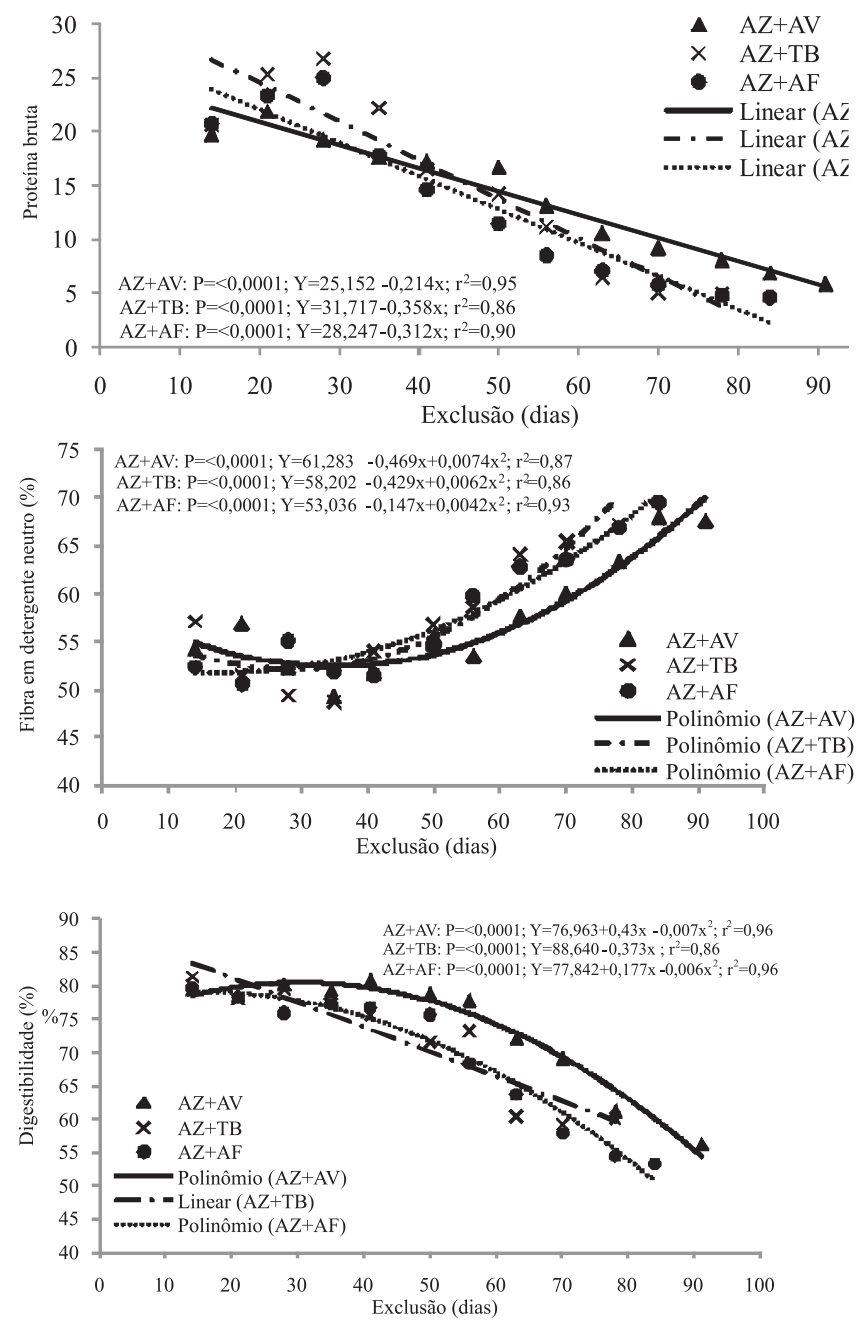

Figura 3 - Valor nutricional do azevém consorciado com aveia, trevo-branco e amendoim-forrageiro durante o período de exclusão.

branco em transferir nitrogênio para o azevém no início do período de exclusão.

Neste estudo as áreas experimentais foram exclusas do pastejo, imediatamente após o segundo pastejo, com isso a contribuição de trevo-branco começou a declinar após os 35 dias de exclusão, em virtude da baixa intensidade luminosa incidente sobre a leguminosa, em função do hábito de crescimento ereto do azevém. Dessa forma, possivelmente a máxima expressão do potencial do trevo-branco foi limitada, uma vez que essa leguminosa concentra sua produção durante os meses de inverno e principalmente no início da primavera, caracterizando-se como uma espécie hiberno-primaveril. O azevém consorciado com amendoim-forrageiro apresentou maior teor de PB no início do período de exclusão se comparado ao azevém consorciado com aveia. Esse comportamento deve-se à maior produção de folhas nesse período inicial para o tratamento composto por amendoim-forrageiro.
Gonçalves \& Quadros (2003) observaram que a taxa de elongação foliar do azevém foi maior para as pastagens adubadas com $180 \mathrm{~kg} / \mathrm{ha}$ de $\mathrm{N}$ e $120 \mathrm{~kg} / \mathrm{ha}$ de $\mathrm{N}+$ trevo vesiculoso. Devido à ausência de diferença estatística, os autores comentaram que a leguminosa foi eficiente em transferir nitrogênio para a gramínea acompanhante no período inicial de avaliação. Outra hipótese é que a dose de $120 \mathrm{~kg} / \mathrm{h}$ de $\mathrm{N}$ foi suficiente para manter a taxa de elongação foliar, independentemente da leguminosa. Collins et al. (1991) relataram que normalmente há pouca transferência durante os primeiros meses após a semeadura de uma pastagem consorciada com gramínea e leguminosa, e que a maior rota de transferência de nitrogênio, tanto sob pastejo quanto corte, é pela decomposição de material morto de leguminosas, incluindo raízes, estolhos e folhas.

Entre os períodos, a porcentagem de PB foi maior no início do período de exclusão, o que está de acordo com diversos resultados de pesquisas com misturas de aveiapreta e azevém, e de leguminosas com azevém. Os valores de digestibilidade no início da utilização da pastagem foram maiores e foram ocasionados pelo pleno crescimento vegetativo do azevém. A menor digestibilidade observada no último período coincidiu com o final do ciclo de produção do azevém e com o maior percentual de material morto da pastagem. Esse mesmo comportamento foi observado por Difante et al. (2006) em pastagens de azevém adubadas com nitrogênio.

O comportamento da PB foi linear em todos os pastos. A redução dos teores de PB no azevém consorciado com aveia foi mais branda que nos demais pastos. Os teores de FDN do consórcio de azevém e aveia-preta a partir dos 41 dias de exclusão foram menores que nas outras pastagens. A digestibilidade in vitro da matéria orgânica ajustou-se ao modelo de regressão quadrático para azevém + aveiapreta e azevém + amendoim-forrageiro e linear para azevém + trevo-branco. O azevém consorciado com aveia apresentou maior digestibilidade in vitro da matéria orgânica, principalmente após os 35 dias de exclusão. Esses fatores possivelmente estão relacionados ao maior período em estádio vegetativo do azevém quando consorciado com a aveia, uma vez que a relação folha/colmo permaneceu elevada por mais tempo, ocasionando inversão dos componentes folha e colmo tardiamente, após 56 dias de exclusão.

Em geral, além do maior percentual de $\mathrm{PB}$, as folhas possuem menores concentrações de FDN, FDA e lignina em comparação aos colmos (Van Soest, 1994). Após os 63 dias de exclusão, nas pastagens de azevém + trevo-branco e azevém + amendoim-forrageiro, os teores de PB foram inferiores a $10 \%$, insuficientes até mesmo para atender às exigências de bovinos leiteiros durante o período seco 
(NRC, 2001). A maior produção de colmos em relação às folhas ocorreu aos 41 e 35 dias, respectivamente, e constitui um importante parâmetro para definir o momento da entrada dos animais nas pastagens, já que o início do estádio reprodutivo cessa a emissão de folhas e define a produção forrageira, com valores de FDN entre 50 e 55\%.

O consumo de MS é uma variável importante que afeta o desempenho animal, Mertens (1987) relata que o elevado teor de FDN é o fator mais limitante do consumo. Quando a PB da forragem atinge níveis inferiores a 7\% e os teores de FDN superam 60\%, ocorre acentuada redução no consumo da forragem (Van Soest, 1994). Segundo Conrad (1964), o enchimento físico é limitante ao consumo de MS de dietas com digestibilidade abaixo de $66 \%$ e controles metabólicos limitam o consumo de dietas com digestibilidade superior a esse valor. A estrutura da pastagem também influencia o consumo de MS. Os animais concentram a atividade de pastejo nas camadas de pastagem que possuem principalmente folhas (Hogdson, 1990). Segundo Minson (1990), os animais selecionam as folhas por serem mais acessíveis e de menor resistência à apreensão e de melhor qualidade. Dessa forma, a avaliação dos parâmetros botânicos, estruturais e nutricionais das pastagens pode ser utilizada de forma integrada para definição do melhor intervalo entre pastejos.

De acordo com Rocha et al. (2007), o avanço no desenvolvimento do ciclo dos cultivares ocasionou redução da proporção de folhas e aumento de colmos e material morto, o que alterou a composição química da MS ao longo do ciclo produtivo. Quadros \& Maraschin (1987) em Guaíba, Rio Grande do Sul, estudando o desempenho animal em misturas de espécies forrageiras de estação fria sob pastejo, quantificaram valores de digestibilidade in vitro da matéria orgânica ao longo do período experimental entre 73 e 58\% para as associações de azevém, trevo-branco e cornichão. A redução na qualidade bromatológica da forragem também pode ser explicada pelas altas temperaturas do final do período produtivo, que aceleraram as atividades metabólicas da planta ocasionando decréscimo no conjunto de metabólitos do conteúdo celular. Desse modo, os produtos fotossintéticos são rapidamente convertidos em componentes estruturais (Rocha et al., 2007). As altas temperaturas ambientais também resultam em aumento na lignificação da parede celular e alongamento dos entrenós (Van Soest, 1994).

\section{Conclusões}

O avanço do estádio vegetativo modifica a composição botânica e estrutural das pastagens, reduzindo o valor nutricional do azevém. O consórcio com a aveia altera a composição estrutural do azevém, contribuindo para manutenção do valor nutritivo ao longo do tempo e possivelmente para o aumento do período de utilização da pastagem. O azevém consorciado com trevo-branco apresenta maior teor de proteína bruta, enquanto o amendoim-forrageiro não influencia a composição estrutural e nutricional do azevém.

\section{Referências}

BARCELLOS, A.O.; RAMOS,A.K.B.; VILELA, L. et al. Sustentabilidade da produção animal baseada em pastagens consorciadas e no emprego de leguminosas exclusivas, na forma de banco de proteína, nos trópicos brasileiros. Revista Brasileira de Zootecnia, v.37, p.51-67, 2008 (supl. especial).

CASTRO, C.R.T.; CARVALHO, M.M. Florescimento de gramíneas forrageiras cultivadas sob luminosidade reduzida. Ciência Rural, v.30, n.1, p.163-166, 2000.

COLLINS, R.P.; GLENDING, M.J.; RHODES, I. The relationship between stolon characteristics, winter survival and annual yield in white clover (Trifolium repens L.). Grass Forage Science, v.46, p.51-61, 1991.

COMISSÃO DE FERTILIDADE DO SOLO RS/SC. Manual de adubação e calagem para os Estados do Rio Grande do Sul e Santa Catarina. 10.ed. Porto Alegre: SBCS - Núcleo Regional Sul: UFRGS, 2004. 400p.

CONRAD, H.R.; PRATT, A.D.; HIBBS, J.W. Regulation of feed intake in dairy cows. 1 . Change in importance of physical and physiological factors with increasing digestibility, Journal of Dairy Science, v.47, n.1, p.54-62, 1964.

DIFANTE, G.S.; MARCHEZAN, E.; VILLA, S.C.C. et al. Produção de novilhos de corte com suplementação em pastagem de azevém submetida a doses de nitrogênio. Revista Brasileira de Zootecnia, v.35, n.3, p.1107-1113, 2006.

EMPRESA BRASILEIRA DE PESQUISA E AGROPECUÁRIA EMBRAPA. Centro Nacional de Pesquisa de Solos. Sistema brasileiro de classificação de solos. Rio de Janeiro, 1999. 412p.

GOERING, H.K.; VAN SOEST, P.J. Forage fiber analysis: apparatus reagents, procedures and some applications. Washington, D.C.: Agricultural Hantbook, 1970. 379p.

GONÇALVES, E.D.; QUADROS, F.L.F. Características morfogênicas de azevém anual (Lolium multiflorum Lam.) sob pastejo em sistemas intensivos de utilização. Ciência Rural, v.33, n.6, p.1129-1134, 2003.

GRISE, M.M.; CECATO, U.; MORAES, A. et al. Avaliação da composição química e da digestibilidade in vitro da mistura aveia IAPAR 61 (Avena strigosa Schreb) + ervilha forrageira (Pisum arvense L.) em diferentes alturas sob pastejo. Revista Brasileira de Zootecnia, v.30, n.3, p.659-665, 2001.

HERINGER, I.; MOOJEN, E.L. Potencial produtivo, alterações da estrutura e qualidade da pastagem de milheto submetida a diferentes níveis de nitrogênio. Revista Brasileira de Zootecnia, v.31, n.2, p.875-882, 2002 (supl.).

HODGSON, J. Grazing management: science into practice. Essex: Longman, 1990. 203p.

LAMBERS, H.; CHAPIN III, F.S.; PONS, T.L. Plant physiolgical ecology. New York: Springer, 1998. 540p.

MERTENS, D.R. Predicting intake and digestibility using mathematical models of ruminal function. Journal Animal Science, v.64, n.6, p.1548-1558, 1987. 
MORENO, J.A. Clima do Rio Grande do Sul. Porto Alegre: Secretaria da Agricultura. 1961. 41p.

NATIONAL RESEARCH COUNCIL - NRC. Nutrient requeriments of dairy cattle. 7.ed. Washinton, D.C.: 2001. 381p.

QUADROS, F.L.F.; MARASCHIN, G.E. Desempenho animal em misturas de espécies forrageiras de estação fria. Pesquisa Agropecuária Brasileira, v.22, n.5, p.535-541, 1987.

ROCHA, M.G.; QUADROS, F.L.F.; GLIENKE, C.L. et al. Avaliação de espécies forrageiras de inverno na Depressão Central do Rio Grande do Sul. Revista Brasileira de Zootecnia, v.36, n.6, p.1990-1999, 2007.
RYLE, G.J.A. Effects of shading on inflorescence size and development in temperate perennial grasses. Annals of Applied Biology, v.59, n.2, p.297-308, 1967.

STATISTICAL ANALYSIS SYSTEM - SAS. User's guide. Version 8.02. Cary: Statistical Analysis System Institute, 2001. 943p

TILLEY, J.M.A.; TERRY, R.A. A two stage technique for the in vitro digestion of forage crops. Journal of the British Grassiand Society, v.18, n.2, p.104-111, 1963.

VAN SOEST, P.J. Nutritional ecology of the ruminant. 2.ed. Ithaca: Cornell University, 1994. 476p. 